\title{
Evaluation of Beal Genotypes for Biochemical Characters
}

\author{
P. Pavani", G. Harshavardhan, S. N. Das and B. K. Das \\ Department of fruit science and horticulture technology, College of Agriculture, \\ OUAT, Bhubhaneswar, Odisha, India \\ *Corresponding author
}

\section{A B S T R A C T}

\begin{tabular}{|l|}
\hline Ke y w o r d s \\
Bael, Accessions, \\
hand refractometer, \\
Titrable acidity, \\
Ascorbic acid
\end{tabular}

\section{Introduction}

Bael (Aegle marmelos Correa) occupies an important place among indigenous fruits of India due to its nutritional, medicinal and pesticidal values. In the absence of suitable cultivars, expected growth in production of this crop has not been accomplished till date. Identification of suitable genotypes, therefore, becomes imperative for promoting its production, productivity and quality.

A wide range of variation is encountered in bael (Rai et al., 2005) as it was largely propagated through seeds until recently. However, very little efforts have been made to quantify the genetic variability present in it and its utilization in crop improvement. So proper attention is needed on its collection, evaluation and conservation of genetic pool. Selection and exploitation of the promising genotype would be of immense value for commercialization.

As with any crop, plant breeding programme with fruit crops depends on knowledge of key traits, genetic system controlling their inheritance and genetic and environmental factors that influence their expression. The information about the nature and magnitude of genetic variability as well as associations among key traits would be helpful in formulating an effective breeding programme for its genetic improvement. Therefore, an 
attempt has been made to evaluate and exploit genetic variability in beal fruits grown in Odisha. The information on aspects would be of great significance in formulating appropriate breeding strategy for genetic up gradation of this valuable crop.

Significant workers have also researched upon bael for its various characters. The characters studied by other workers have been tree, fruit, pulp and biochemical characters. A high degree of variation have been reported in this characters notably among them are singh et al., Kumar et al., Pandey et al., and Nath et $a l$., The present study entitled "Evaluation of Bael Genotypes for Biochemical Characters" aims to identify and screen superior accessions of bael and gather information on variability in bio-chemical characters.

\section{Materials and Methods}

The present experiment was undertaken during 2013 with an objective to evaluate 20 different genotypes collected from Dhenkanal district and Bhubaneswar for different biochemical characters. The analysis of different characters was carried out in the experimental laboratory of Department of Fruit Science and Horticulture Technology, Orissa University of Agriculture and Technology, Bhubaneswar. Various procedures of sample collection and analysis followed during the research have been described. The method of random sampling from a population and biased sampling after gathering information about a particular genotype was followed. Randomly selected fruits were used to record the biochemical characters. The extents of variation in physico-chemical traits of fruits from different locations were recorded.

Moisture percentage of the pulp was calculated by completely drying the fresh pulp as suggested by Vijai kumar et al., (2009).
Total soluble solids of the fruit were recorded with the help of a Hand Refractometer in degree brix. Initially the reading was adjusted to zero by placing few drops of distilled water on the prism of the refractometer. Juice was prepared from the ripe pulp and a few drops of the juice were placed on the prism of the refractometer. Necessary temperature correction was made and final TSS reading was observed. Three separate readings were recorded for a single juice sample and the average was taken (Ranganna, 1986).

The acidity of the ripe fruits of different accessions was estimated by using procedure described by Ranganna (2000) after ripening. A clear homogenized juice was taken in $100 \mathrm{ml}$ conical flask. One to drops of phenolphalein indicator was added to it. Then the diluted sample was titrated against $0.1 \mathrm{~N}$ sodium hydroxide solution taken in a burette. The end point of titration was indicated by a faint pink colour. Titration was continued till three current readings were obtained. Percentage of acidity is calculated by using the formulae with the obtained titrated values. The acidity percentage of the juice in terms of citric acid was calculated adopting the following formula.

$\%$ citric acid $=$ (Titre value $\mathrm{x}$ Normality of $\mathrm{NaOH} x$ meq wt. of acid $\mathrm{x}$ volume made up to / Volume of sample taken for estimation $\mathrm{x}$ Volume of sample taken x 1000) X 100

Note:

meq $=$ milliequivlent

(Meq of citric acid $=0.06404$ )

Reducing sugars present in the juice was determined by following standard methods. First $10 \mathrm{ml}$ of the juice was taken in a $100 \mathrm{ml}$ volumetric flask and made up to the mark by adding distilled water. Then it was transferred to a $100 \mathrm{ml}$ burette. Then $5 \mathrm{ml}$ each of Fehling's A and Fehling's B were taken in a 
$250 \mathrm{ml}$ capacity conical flask along with $40 \mathrm{ml}$ of distilled water and the contents were thoroughly mixed. It was placed over gas flame and heated. When the first bubble appeared, 2-3 drops of methylene blue were added and it was simultaneously titrated against the juice sample taken in the burette till the end point of a brick red colour, was obtained. The reducing sugar was calculated by the following formula assuming that $10 \mathrm{ml}$ Fehling's solution A and B is equivalent to $0.05 \mathrm{~g}$ of glucose (A.O.A.C.1975).

\section{$0.05 \mathrm{x}$ juice dilution}

Reducing sugar \% = -------------------- x 100

Titre value $\mathrm{x}$ Volume of sample taken

In order to determine the content of nonreducing sugar in the sample first total sugar content was estimated. For the conversion of non-reducing sugar to reducing form $10 \mathrm{ml}$ of filtrate juice was taken in a $250 \mathrm{ml}$ volumetric flask and $5 \mathrm{ml}$ of $1 \mathrm{~N}$ HCL was added to it followed by addition of $30 \mathrm{ml}$ distilled water.

Then the content was heated for 4-5 minutes and then cooled (for inversion). Then it was transferred to a $250 \mathrm{ml}$ conical flask and titrated against $1 \mathrm{~N} \mathrm{NAOH}$ solution taken in a burette after the addition of 2-3 drops of phenolphthalein indicator to the juice sample until a light pink colour end point was obtained. This was done to make the juice sample neutral in reaction. Thus the nonreducing sugar present in the juice was converted to reducing state. After this, the same procedure was adopted as followed in reducing sugar. Total sugar was calculated by the following formula. (A.O.A.C. 1975)

$0.05 \mathrm{x}$ juice dilution

Total sugar \% = -------------------------- X 100

Titre $\mathrm{x}$ Volume of sample taken

The percentage of non-reducing sugar in the juice sample was calculated by the formula,
$\%$ of Non-reducing sugars $=($ Total sugar $\%-$ $\%$ of Reducing sugars) x 0.95

In order to estimate the ascorbic acid, first a dye solution was prepared by addition of 42 mg sodium bicarbonate (dissolved in distilled water) and 52mg 2,6-dichloro phenol indophenols and the volume was made up to $200 \mathrm{ml}$ by adding distilled water. Then stock solution and working standard solution were prepared. Then $5 \mathrm{ml}$ of standard solution was taken in a $100 \mathrm{ml}$ volumetric flask and $10 \mathrm{ml}$ of $4 \%$ oxalic acid was added to it. The sample was titrated against the dye until an end point of pink colour persisting for a few minutes was observed. Ascorbic acid was calculated by using the following formula: (Srivastava and Sanjeev kumar, 1994)

Amount of

Titre $\mathrm{x}$ Dye factor $\mathrm{x}$ Volume made upto 100 Ascorbic acid $(\mathrm{mg} / 100 \mathrm{mg})=$ $\mathrm{x} 100$ Volume of filtrate taken $\mathrm{x}$ Volume of sample taken

Where,

Dye factor $=$ - - Titre of dye solution

Sugar/acid ratio is estimated as a ratio of percentage of total sugar to the percentage of total acid.

\section{Results and Discussion}

The data pertaining to biochemical attributes of bael showed significant differences and high degree of variability for all the characters studied. Wide variations in bio-chemical composition of fruits were observed. The TSS content varied from $25.62^{\circ} \mathrm{B}$ in Acc. 11 to 33.77 $\mathrm{B}$ in Acc.19. The accessions 1, 2, 3, 4, $5,8,12,14,16$ and 20 had TSS content more than $30.8^{\circ} \mathrm{B}$. 
Table.1 TSS, acidity, ascorbic acid and moisture content of the pulp

\begin{tabular}{|c|c|c|c|c|}
\hline Acc. No & TSS $\left({ }^{0}\right.$ brix $)$ & Acidity \% & $\begin{array}{c}\text { Ascorbic acid } \\
\text { mg/100g }\end{array}$ & $\begin{array}{c}\text { Moisture content } \\
\%\end{array}$ \\
\hline Acc-1 & 31.40 & $\mathbf{1 . 1 1}$ & 29.00 & 50.74 \\
\hline Acc-2 & 33.00 & 0.45 & 23.62 & 45.50 \\
\hline Acc-3 & 30.96 & 0.99 & 17.57 & 52.84 \\
\hline Acc-4 & 32.73 & 0.63 & 17.37 & 54.05 \\
\hline Acc-5 & 33.61 & 0.84 & 18.01 & 52.42 \\
\hline Acc-6 & 27.10 & 0.91 & 18.49 & 52.55 \\
\hline Acc.7 & 26.67 & 0.96 & 12.24 & 48.86 \\
\hline Acc-8 & 33.69 & 0.73 & 13.85 & 50.43 \\
\hline Acc-9 & 28.07 & 0.43 & 18.18 & 49.27 \\
\hline Acc-10 & 26.01 & 0.88 & 14.32 & 37.15 \\
\hline Acc-11 & 25.62 & 1.10 & 22.34 & 52.14 \\
\hline Acc-12 & 31.20 & 0.75 & 23.84 & 51.16 \\
\hline Acc-13 & 28.86 & 0.40 & 18.53 & 49.43 \\
\hline Acc-14 & 32.88 & 0.94 & 18.32 & 46.56 \\
\hline Acc-15 & 30.56 & 0.47 & 12.23 & 49.40 \\
\hline Acc-16 & 32.13 & 0.60 & 12.59 & 50.26 \\
\hline Acc-17 & 26.58 & 0.32 & 14.99 & 48.99 \\
\hline Acc-18 & 30.53 & 0.63 & 18.63 & 46.78 \\
\hline Acc-19 & 33.77 & 0.50 & 18.11 & 51.72 \\
\hline Acc-20 & 32.13 & 0.73 & 15.41 & 4.38 \\
\hline CD(0.05) & 2.97 & 0.23 & 5.93 & \\
\hline
\end{tabular}

Table.2 Reducing sugars, non-reducing sugars, total acidity, TSS / acid ratio

\begin{tabular}{|c|c|c|c|c|}
\hline Acc. No & $\begin{array}{c}\text { Reducing sugars } \\
\%\end{array}$ & Non reducing sugars \% & Acidity & TSS/acid ratio \\
\hline Acc-1 & 7.40 & 7.32 & 1.11 & 13.75 \\
\hline Acc-2 & 9.24 & 5.33 & 0.45 & 25.08 \\
\hline Acc-3 & 7.65 & 3.64 & 0.99 & 11.24 \\
\hline Acc-4 & 7.95 & 5.76 & 0.63 & 12.63 \\
\hline Acc-5 & 6.05 & 5.56 & 0.84 & 16.55 \\
\hline Acc-6 & 4.57 & 6.53 & 0.91 & 12.23 \\
\hline Acc.7 & 6.92 & 3.79 & 0.96 & 10.53 \\
\hline Acc-8 & 5.43 & 4.72 & 0.73 & 10.90 \\
\hline Acc-9 & 11.32 & 4.64 & 0.43 & 22.46 \\
\hline Acc-10 & 12.66 & 4.25 & 0.88 & 19.33 \\
\hline Acc-11 & 12.54 & 3.55 & 1.10 & 14.85 \\
\hline Acc-12 & 9.83 & 4.73 & 0.75 & 19.84 \\
\hline Acc-13 & 14.7 & 5.07 & 0.40 & 46.67 \\
\hline Acc-14 & 10.85 & 3.42 & 0.94 & 15.69 \\
\hline Acc-15 & 10.98 & 4.33 & 0.47 & 33.93 \\
\hline Acc-16 & 12.37 & 5.79 & 0.60 & 30.51 \\
\hline Acc-17 & 5.46 & 5.99 & 0.32 & 37.47 \\
\hline Acc-18 & 17.7 & 6.93 & 0.63 & 40.31 \\
\hline Acc-19 & 13.19 & 4.11 & 0.50 & 35.40 \\
\hline Acc-20 & 15.23 & 3.24 & 0.73 & 25.52 \\
\hline CD(0.05) & 1.19 & 1.28 & 0.23 & 7.90 \\
\hline
\end{tabular}


The titrable acidity was found minimum in Acc.17 (0.32 \%) and maximum (1.11\%) in Acc.1. The non-reducing sugars ranged from $3.24 \%$ in Acc.20 to $7.32 \%$ in Acc.1. The reducing sugar was found maximum in Acc.20 (15.23\%) and minimum in Acc.6 $(4.57 \%)$. The vitamin ' $\mathrm{C}$ ' was the highest in Acc. $1(29.00 \mathrm{mg} / 100 \mathrm{~g})$ and lowest in Acc. 15 $(12.23 \mathrm{mg} / 100 \mathrm{~g})$. The TSS/acid ratio ranged from 23.96 to 84.73 among the various types. The highest TSS/acid ratio was found in Acc.17, while minimum in Acc.11.

The findings from the present experiment shows that Acc.2, 4, 16 and 19 were very encouraging for fruit quality character.

\section{Acknowledgement}

I am very much thankful to my guide and members of Horticultural Research Stataiton, OUAT, Bhubaneswar, of their help and cooperation during the course of my research work. I am overwhelmed with gratitude to all my respondents, without whose whole hearted co-operation, this study would not have been fruitful. Above all I am extremely thankful and grateful to God who has blessed me to be what I am today.

\section{References}

Dinesh Kumar*1 and Vishal Nath2 Variability in Bael (Aegle marmelos Correa) Genotypes from Orissa 1Central Institute of Temperate Horticulture (ICAR), Rangreth, Srinagar-190 007, J\&K 2Central
Horticultural Experimental Station (IIHR), Bhubaneswar-751 019, Orissa

Majumder B.C. 1975. Physico-chemical analysis of some types of bael (Aegle marmelos Correa). I. Fruit growing in West Bengal. Indian Agric. 19: 295-98.

Pandey D.*, Shukla S.K., Kumar A.

Variability in bael accessions from Bihar and Jharkhand, Central Institute for Subtropical Horticulture, Rehmankhera, PO Kakori, Lucknow 227107. Indian Journal of Horticulture Year: 2008, Volume: 65, Issue: 2 First page: (226) Last page: (229) Print ISSN: 0972-8538.

Rai. M., Gupta P.N., Dwivedi R. 1991. Variability in bael germplasm. Indian J. Plant Gen. Resour. 40: 86-91.

Singh R., Misra K.K., Jaiswal H.R. 2000. Studies on physico-chemical characters of fruits of bael genotypes. Indian $J$. Hort. 57: 314-17.

Singh, V.P., and K.K. Misra* (2008) Variability and character association analysis in bael germplasm, Department of Horticulture, G.B. Pant University of Agriculture and Technology, Pantnagar 263145

Srivastava, A.K., Singh. H. K. and Prasad. J. 1998. Genetic diversity. Bael (Aegle marmelos Correa). Indian Horticulture, 42 (2): cover page-II.

Vijai Kumar, Pooja Sapra1, Vandana Umrao2 and Vinod Pal Genetic variability in bael (aegle mar!v'elos correa) fruits grown in western Uttar pradesh. Department of Horticulture, Ch. 8.8. Shandilya (P.G.) College, Machhra, Meerut-250 106, Uttar Pradesh.

\section{How to cite this article:}

Pavani P., G. Harshavardhan, S. N. Das and Das B. K. 2018. Evaluation of Beal Genotypes for Biochemical Characters. Int.J.Curr.Microbiol.App.Sci. 7(06): 2930-2934. doi: https://doi.org/10.20546/ijcmas.2018.706.344 